\title{
On Morris Low's Building a Modern Japan: Science, Technology, and Medicine in the Meiji Era and Beyond
}

\author{
(New York: Palgrave Macmillan, 2005)
}

\author{
Dong-Won Kim
}

Received: 4 May 2007 / Accepted: 4 May 2007/

Published online: 30 January 2008

(C) National Science Council, Taiwan 2007

Ever since Joseph Needham published the first volume of Science and Civilisation in China in 1954, many important works have been produced on East Asian science, technology, and medicine in the pre-modern period. The history of science, technology, and medicine in the nineteenth and twentieth centuries, however, has been largely neglected. It began to attract some attention only recently with the rapid economic growth in the region. Morris Low's edited volume of Osiris (Volume 13, 1998), with the title of Beyond Joseph Needham: Science, Technology, and Medicine in East and Southeast Asia, was a notable example of the new direction of the field: eleven out of twelve case-studies were about the nineteenth and twentieth century; and five of them were on Japanese science, technology, and medicine. Low has done a marvelous editorial job once again in his new book, Building a Modern Japan: Science, Technology, and Medicine in the Meiji Era and Beyond, which is a very valuable addition to this rapidly growing field.

The Meiji era (1868-1912), which is the focus of Building a Modern Japan, was the most glorious and also most turbulent time in Japanese history. As Low states in the introduction, the Meiji Restoration "ushered in a program of modernization that involved not just opening Japan to trade with the West but participating in a global system of knowledge - 'foreign intercourse' in the broadest sense of the term" (p. 2). During this period, Japan enthusiastically adopted Western-style systems of politics, economics, education, science, technology and medicine, and transformed itself into a modern, industrialized nation. Japanese industry began to dominate trade in East and Southeast Asian markets. The Japanese military defeated the Chinese army and navy in 1894-1895, and also vanquished Russian forces on land and at sea in 19041905. Japanese science, technology, and medicine left a long-lasting influence on China, Korea and Taiwan. Japan indeed became the model for other Asian countries who were desperately trying to modernize themselves. This unique success of Meiji Japan attracted the interest of Western scholarship including history of science,

D.-W. Kim $(\bowtie)$

Department of History of Science and Technology, Johns Hopkins University, Baltimore, MD, USA e-mail: dwkim3@yahoo.com 
technology, and medicine. Two good examples were James R. Bartholomew's The Formation of Science in Japan: Building a Research Tradition (1989) and Tessa Morris-Suzuki's The Technological Transformation of Japan: From the Seventeenth to the Twenty-First Century (1994), in which the authors provided excellent introductions for the development of science and technology in the Meiji period. The detailed case-studies that Low has carefully collected in his new book can be considered as offspring from this line of Japanese studies in modern period.

Building a Modern Japan consists of nine case-studies that are divided into two parts. The first part examines how the Japanese government, the country's scientific and medical communities, and Western knowledge worked together to improve public health. Christian Oberländer and Sabine Frühstück each examine how the Japanese adopted Western medicine and scientific knowledge to treat beriberi and neurasthenia. Beriberi attracted the government's attention in the late 1870 s because it afflicted so many soldiers and sailors. Japanese medical men set up a new hospital that was dedicated to the cure and research of beriberi, and adopted western scientific theories and experimental technique in order to discover "beriberi bacillus." Although the empirical knowledge proved more effective in curing and preventing the disease than western approaches, this "government-sponsored research program of hospital medicine" (p. 29) greatly influenced the development of Japanese medicine. Neurasthenia was also a threat to the health and well-being of the nation since mental weakness was as fatal as physical weakness. Frühstück shows that the introduction of sexological discourses from the West during the 1920s not only explained the cause of neurasthenia but also enabled the Japanese medical men to discuss freely sexual practice, sexuality and gender in the conservative Japanese society.

Sumiko Otsubo and Yuki Terazawa analyze how the Japanese medical men adopted and modified Western ideas about eugenics and gender in order to influence the reproductive lives of Japanese people. Otsubo's chapter discusses Osawa Kenji, Tokyo University professor of physiology, who emphasized the female body for the improvement of the Japanese race. Osawa's agenda included the issuing of prenuptial health certificates and the eugenic control of marriage, which paved the way for state intervention in the private lives of the Japanese people. Terazawa's chapter focuses on physician Yamazaki Masashige who compared the menstruation of women of different ethnic groups within the Japanese empire. This study shows "how scientific and medical discourses on race were developed in conjunction with discourses and policies associated with Japan's nation- and empire-building projects in the late nineteenth and early twentieth centuries" (p. 83).

Robert John Perrin's study illustrates how Japan's modernization project was exported to and carried out in its colonies and in territories under its influence. Perrin argues that "Modern, Western science in the forms of engineering, urban planning and medicine played a central role in the development of the Japanese colony in southern Manchuria" (p. 123). The New South Manchuria Railway Hospital with its state-of-art facilities was a good example. All these "modern" things and public health policies were to protect Japanese investment and to justify Japanese colonial rule in the region. 
The four case-studies of the second part deal with technology and industry in Meiji Japan. The Japanese were not just passive recipients of Western technology but very able innovators and shrewd businessmen. David G. Wittner's and Martha Chaiklin's chapters analyze how the Japanese selected and imported silk and sheet glass technologies from the West. Although the Japanese industries made some serious errors in the beginning, they eventually adapted the Western technologies. Both cases also show that "[government's] guided choice of technique and technology transfer was more ideological than technical or economic" (p. 136). This often proved the source of the failure in the early stage since the Japanese government preferred the most advanced technologies to medium-level ones, with no regard either for the Japanese market or for the Japanese ability to digest them.

Despite the Japanese government's strenuous effort to modernize its technology, they were not always successful. Gregory Clancey examines how imported Western technology reshaped and redefined the role of Japanese carpenters (daiku). Traditional Japanese carpenters not only survived in "modern" Japan but also influenced and worked with Western-style architects. The Japanese-Western mixed (wayô setchû) architecture proves that new imported Western technology did not completely replace the indigenous one as it often did during the Meiji period. W. Miles Fletcher III's study of the Japanese cotton textile industry during the Great Depression also indicates that the Japanese government's role was not effective enough to meet the grave challenge. It was Japanese industrialists who voluntarily formed the Japan Spinners Association and overcame this unprecedented economic depression by controlling the domestic production and the export trade while improving the technology itself.

The articles in this book show the difficulties and peculiarities of the history of East Asian science, technology, and medicine in the nineteenth and twentieth centuries: the field is between East Asian studies and the history of science, technology, and medicine. As the first generation of historians of sciencetechnology-medicine struggled to maintain the balance between history and science-technology-medicine, the authors in this book are struggling to maintain the balance between Japanese history and history of science-technology-medicine. For example, the authors" overemphasis on "modernity" or "modernization" can be understood in this unique situation. It is quite true that the development of science, technology, and medicine during the Meiji era was closely related to the movement of modernity in the period. However, the formation and development of each professional community during the Meiji period were equally important, something that is largely neglected in the book. So, it remains as a challenge for future scholarship.

Lastly, two minor complaints should be added. First, the book does not include any articles on the history of mathematics, physics, chemistry or geology. These fields were not only equally important during the Meiji period but also advanced enough to be recognized by Western scientists. Japanese physicists, for example, began to publish many quality papers in prestigious Western journals like Nature, Proceedings of the Royal Society of London, Philosophical Magazine, Zeitschrift für Physik, or Physical Review from the beginning of the twentieth century. 
The omission of other fields of science and the multiple articles on eugenics or gender in the first part may give the false impression that Japanese scientists in the Meiji era made no significant progress in these fields. Second, the order of Japanese names may cause some confusing. Low makes it clear in the preface that Japanese names are put as they are called in Japan-surnames first, followed by given name. However, it is still a problem for most Western readers, since many western names appear alongside Japanese names. 